$\begin{array}{r}\text { Volume and Issues Obtainable at Center for Sustainability Research and Consultancy } \\ \text { Journal of Business and Social Review in Emerging Economies } \\ \text { ISSN: 2519-089X (E): 2519-0326 } \\ \text { Volume 6: No. 4, December 2020 } \\ \text { CSRC } \\ \text { Journal homepage: www.publishing.globalcsrc.org/jbsee } \\ \hline\end{array}$

\title{
Assessing the Mediating Role of Organization Learning Capability between the Relationship of Green Intellectual Capital and Business Sustainability
}

\author{
${ }^{1}$ Muhammad Rizwan Sabir, ${ }^{2}$ Muqqadas Rehman, ${ }^{3}$ Waheed Asghar \\ ${ }^{1}$ Ph.D Scholar, Superior University, Lahore, Pakistan, justrizig@ gmail.com \\ ${ }^{2}$ Director, IBA, University of the Punjab, Lahore, Pakistan, muqqadasrehman@hcc.edu.pk \\ ${ }^{3}$ Director, TEVTA, Punjab, Lahore, Pakistan, waheedasgharpk@ gmail.com
}

\begin{tabular}{l}
\hline ARTICLE DETAILS \\
\hline History \\
Revised format: November \\
2020 \\
Available Online: \\
2020 \\
\hline Keywordsrember \\
Green Human \\
Structural rital, Green \\
Organization Capital, \\
Capability, Learning \\
Sustainability.
\end{tabular}

JEL Classification

Q01; Q34

\section{OPEN $\odot$ ACCESS}

\section{ABSTRACT}

There has been a lot of debate on intellectual capital and its dimensions, except green intellectual capital (GIC). The economic benefit of business not only eliminates the neediness of the region but also invigorate the prosperity in the area; however, the heat of financial interest among business competitor causes social inequality and destruction of the environment. Present research is presenting novel conception as paucity in prior literature was being seemed which identify lack of literature regarding relationship between two major concepts Green Intellectual Capital and the concept of business sustainability, by exploring in the context of developing country such as Pakistan. Moreover, study also consider three different dimensions regarding green intellectual capital which is identified from literature, named as green structural capital, green relational capital and green human capital, and also evaluate the mediating role of organization learning capability (OLC) between the relationship of GIC and BS. For this purpose, "Natural Resource-Based View and Intellectual Capital-Based View" these two theories are being grounded to support the model regarding various variables. Data were collected from 154 SME manufacturing companies in Lahore, Pakistan. The simple random sampling technique used for data collection. SPSS and AMOS software is used for data analysis. Result of collected data shows that all the considered three dimensions of green intellectual capital effect on business sustainability. While discussing the mediation, results shows that organizational learning capability is considered a vital mediator element in-between the human capital and business sustainability. Furthermore, OLC does not play a mediation role between structural capital, relational capital, and business sustainability. Finally, this study described limitations as well as future directions.

(C) 2020 Center for Sustainability Research and Consultancy Pakistan under a Creative Commons Attribution-NonCommercial-ShareAlike 4.0

Corresponding author's email address: justrizig@gmail.com

Recommended citation: Sabir, M. R., Rehman, M. \& Asghar, W. (2020). Assessing the Mediating Role of Organization Learning Capability between the Relationship of Green Intellectual Capital and 
Business Sustainability. Journal of Business and Social Review in Emerging Economies, 6(4), 12891301.

\section{Introduction}

The topic of Sustainability is getting more attention and interest in academics as well as practitioners. There has been seen extensive deliberation and discussion regarding the conception of Sustainability. A wide range of discussion is available on the significance of Sustainability along with the different ways and means which is used for achieving and retaining it. The profits which are concerned about the activities economically done in business is increasing the prosperity as well as the conditions of living all over the world; nonetheless, it is leading towards the destructing the environment along with inequality in society which is caused directly or through some other factors (Sullivan et al., 2018). The literature also indicated that the destruction in the environment is taking place and it has measured that almost $60 \%$ of the environmentally friendly systems have been besmirched on a global level (Gong et al., 2018). There is a need to take the step for solving the problems which are existing in the environment; if it is not solved, then it will be increasing and continue to worsen the situation. On the other hand, several companies are not considering the problems by saying that these are not due to the activities of an organization which is impacting the environment, and they are just ignoring the issue. Moreover, all the firms were not agreeing on the concept of Sustainability. The backgrounds and scenarios of business are same as it was in the past, it has turned to be more different from the previous landscape of business because the resources are limited, the use of technology is increasing, the markets are developing, and the updated models used in the business is interfering the traditional methods (Sullivan et al., 2018). Concept regarding sustainability in business was firstly applied to deal through the destruction and degradation in the natural environment along with its negative influence on the health of human beings, societal wellness, and the growth in the economy.

The World Commission has defined the term of sustainability as the positive progression or development in business activities according to need of present era without compromising the past or future generation. This is used in literature extensively and also applied to the three main results, named "economic, social, and environmental." The issue needs quick attention; it should be discussed in the different firms, countries, and regions because these all are changing a begun to use updated and diverse ways. They are vigorously observing the different and innovative ways out which should be implemented to minimize the negative influence of activities of humans on the environment along with improving the health of the public in which the citizens are living and reaping profit. Nevertheless, numerous firms are still not sure about the steps they need to take and what kind of strategies they should use to deal with it. The regulation and actions taken by the government are not sufficient and adequate for the implementation of Sustainability in firms. For dealing with the shift in the environment, the firms need to develop a strategy which is discretionary however it is compulsory and significant for all of the organization operating in the market (Ray \& Grannis, 2015). In connection with the previous discussion, the different research studies have been undertaken by many researchers which includes adopting the eco-friendly innovation environmentally friendly management of human resource, ecofriendly purchasing, low development of carbon as well as for the applicability of ecological supply chain (Aboelmaged \& Hashem, 2019; Zaid et al., 2018; Jabbour \& Jabbour, 2016; Zhang et al., 2018). The trend of research is increasing in the eco-friendly activities of the business. Besides this, investing for the development of intellectual capital is also related to protecting the environment, which is indicated as "green intellectual capital (GIC)," which is taking into account both gaining and sustaining competitive edge and meeting the needs of environmental management. Additionally, according to the research study of Mårtensson \& Westerberg (2016), the authors emphasized how the organization is developing for the in house skills and abilities with using the last characteristic and features of the strategy of environment. Disappointingly, the elements of in house skills and capabilities are absent in preventing the environment (Cleff \& Rennings, 1999; Sharma \& Correa, 2005). Intellectual capital is a mixture of all the intangible resources (Stewart, 1991), and these resources have the firm which is playing an important role in the organization more willingly than tangible nature resources (Allameh et 
al., 2010). In the new body of knowledge, the association in the IC, and the performance of the firm has been developed. Conversely, GIC is not much known in the researchers and practitioners. It is worth noting that the conception of GIC is a probable and credible solution regarding the concerns of Sustainability, which has been debated in the above discussion. In 2008, Chen, in his research study, firstly acquaints with the conception GIC and the researcher mentioned that it would be used in making continuous improvements in the competitive edge for the brand. GIC is indicated as an entirety of the resources which is tangible or the association of knowledge, which is protecting the environment as well as modernization (Chang \& Chen, 2012; Huang \& Kung, 2011). The three key aspects of GIC are known as "Green Human Capital (GHC), Green Structural Capital (GSC), and Green Relational Capital (GRC)". The central theory of "Natural Resource-Based View" NRBV, which is presented by Hart (1995) along with the "Capital-based View" ICBV developed by Reed et al. (2006), was used in the comprehensive research study. The theory of NRBV is complementing the theory, which is related to the resource-based view (RBV) presented by Penrose (1959). Hart, in his research, indicated that the resources and skills in the environment are essential for an organization in obtaining a competitive advantage is helpful for the firm in the present day as well as in the future. However, from Hart (1995), the theory of RBV is not taking into account the linkage in the natural environment and the firm. Apart from this, the resources of an intangible organization are playing a crucial part in valuing the strategic resources as well as the skills and abilities of the company.

On the other hand, there are some problems and issues in measuring the intangible resources of the organization, which is recognized by the researcher like Bontis (1998). The researchers tried to overcome the restricted assess on measuring the intangible side of the resources by presenting ICBV, which is identified as the models for measurement of capital (Reed et al., 2006). In the main, the model of ICBV focused on the resources which are intangible in nature or the resources that have intellectual nature, and these are divided into three main categories, which are named as "Human, Structural and Relational Capital". Present research study is trying to associate the said theories for conceptualizing the intangible resources, which is leading towards the sustainable business organization with using the integration of green intellectual capital in the traditional intellectual capital. The current study will be undertaken for accessing the links of green intellectual capital and the Sustainability of the business. According to literature, the researchers suggested that for enhancing the Sustainability of the firm intellectual capital is playing a vital role in the organization (Mishal et al., 2017; Cavicchi \& Vagnoni, 2017). On the contrary, earlier research scholars have also proclaimed that the intellectual capital of the firm is leading towards innovation (Allameh, 2018) and also improving the repute and productivity (Bontis et al., 2018). Chen (2011) claimed the popularity of the conception of green politics in the present corporate world. Numerous firms are trying their best to be a highly sustainable organization. Previous research studies observed that the GIC is providing a detailed insight, understanding, and information, which is helping the supervisors and owners of the organization in achieving the best financial performance, along with the eco-friendly competitive advantage (Erinos \& Rahmawati, 2017; Firmansyah, 2017). As a result, it is very significant to create a link in the green intellectual capital and Sustainability of business.

\section{Review Related Literature and Hypothesis Development 2.1 Green Human Capital and Business Sustainability}

According to the point of view of Wright et al. (1994), the researchers recommended that the human capital of the organization is playing an essential role in sustaining the competitive advantage of the organization. From the viewpoint of Subramaniam and Youndt (2005), the capital-related with the human is a leading resource which is plays a vital element in organizational success for the reason that the skills and abilities which are possessed by the employees of the organization are significant for sustaining a business organization in the corporate world that is changing rapidly. Additionally, the theory of Human capital is stating that the skills and abilities which is possessed by the employees are directly related to the productivity of the organization (Davidsson and Honig, 2003). When the employee has a high level of skills and capabilities, it has more chances to be more productive as 
compared to the company in which the employee is less capable. As the current era is more focused on the knowledge, so it is requiring that the organization has the personnel, workforces, administrators, and individual who are solving the problems of the organization to be well-informed and experienced. When the employees are acquiring more knowledge, it will help them in improving their skills. It will be beneficial for the employee to be more productive and enhance their work quality, which will increase productivity (Luthans and Youssef, 2004). At present, the aspect of the environment cannot be ignored by the business. Therefore, GHC role and its impact on the Sustainability of business must be examined. The findings of the study of Yong et al. (2019) showed that GHC is positively influencing the ecofriendly management of human resources. Likewise, the study of Erinos and Rahmawati (2017) concluded that the relation between GRC and financial performance is positive. In the meantime, the study of Chen and Chang (2013) also found that the association in GHC and eco-friendly innovation performance is also positive. The study of Huang and Kung (2011) indicated that GIC is helping the business to follow the worldwide regulations regarding the environment and creating value for the company. Additionally, literature stressed that for achieving Sustainability, human capital is significant (Akhtar et al., 2015). Nonetheless, there is a lack of research that has examined the interrelation in GHC and Sustainability of business. The research hypothesis of the current study is that:

$\mathrm{H}_{1}$ : The association in the green Human Capital and Business Sustainability is positive.

\subsection{Green Structural Capital and Business Sustainability}

The previous study of Widener (2006) proclaimed that when the structures and processes of any firm are weak, the organization cannot be successful. Likewise, when the organization has structural capital that is strong, then it has a more reassuring environment, which is motivating the personnel in learning new information (Bontis et al., 2000; Florin et al., 2002). The previous studies indicated that structural capital is playing an essential role in the performance of the organization (Hsu and Wang, 2012). Moreover, it is necessary for the business that they should develop a structure of environment that is stable and helping to resolve the challenges in climate. It consists of the inside policies (Lee et al., 2015), and practices used in managing low carbon (Raar, 2015; Singh, 2015). Additionally, the eco-friendly culture will help in improving the sales of the organization and decrease the cost (Mehta and Chugan, 2015). Much previous research showed that there is a positive and significant association in the ecological structural capital and the outcomes of the business. According to the study of Chen (2008) and Firmansyah (2017), the studies found that there is an interrelation in the competitive advantage and green structural capital. In the study of Huang and Kung (2011), the results indicated that the link in the GSC and activities related to commitment and competency of the environment is favorable. The study of Delgado-Verde et al. (2014) revealed that the green capital of the organization is positively associated with the ecofriendly innovation of the product. The findings of Erinos and Rahmawati (2017) research showed that GSC is positively affecting financial performance. Furthermore, Akhtar et al. (2015) found that structural capital is playing a significant part in achieving Sustainability. Nonetheless, there is no research study conducted which has examined the interrelation of the GSC and Sustainability of business. So, the hypothesis of the present study is that:

$\mathrm{H}_{2}$ : The interrelation in the Green Structural Capital and Business Sustainability is positive.

\subsection{Green Relational Capital and Business Sustainability}

By using the relational capital, valuable information within the stakeholders is shared. The stakeholders of the organization can provide vital information to the firm. Nelson and Winter (1982) stressed that when collaboration with the partners is high than the firm is likely to have better routine work. The theory of Social Exchange suggests that the link in RC and transaction is comprising of a sophisticated advancement of personal as well as the structure of organization within the company. According to MorganHunt (1994), one of the critical characteristics of the association in the social exchange is faith. When the relationship in partners is based on trust, then the stimulation and learning are enhanced (Doz, 1990), and it will increase the performance of the company (Bonner and Walker, 2004). Many companies who are operating manufacturing concerns are trying to build a strong relationship with the suppliers to develop the required skills and abilities, which will lead to decreasing the cost of product 
and also increase the productivity of the firm (Walter, 2003). Furthermore, strong links will help achieve the goals of the environment (Bicknell and Mcmanus, 2006). Niesten et al. (2016) indicated that the big corporation in the companies, government, and the other institutes is increasing the Sustainability of society. In the recent research of Dickel et al. (2018), it is stated that when the partners are collaborating using green practices, it is increasing the consciousness in many stakeholders that will lead towards minimizing the uncertainty of the environment. Yusoff et al. (2019) claimed that the sharing of knowledge and corporation in the stakeholders is playing a significant role in adopting the approach of Sustainability. Numerous studies highlighted that ecofriendly relational capital is positively connected with productivity. The study of Chen (2008) and Firmansyah (2017) also concluded that competitive advantage and GRC are closely linked. Correspondingly, the study of Huang and Kung (2011) examined that the GRC is has a positive association with the competency of the environment and activities of organization related to commitment. According to Erinos and Rahmawati (2017), the influence of GRC is positive on financial performance. From the research findings of Yong et al. (2019), it is highlighted that the relation in the GRC and ecofriendly management of human resources is positive. Further, Akhtar et al. (2015) revealed that for achieving Sustainability, the role of relational capital is vital. Nevertheless, there is no research conducted to examine the association in the GRC and the suitability of business. So the hypothesis is that:

$\mathrm{H}_{3}$ : Green Relational has a positive influence on Business Sustainability

\subsection{Organizational Learning Capability as a Mediator between Green Intellectual Capital and Business Sustainability}

For examining the role of mediator of the variable of organizational learning capability (OLC), different research studies have been undertaken. The research studies of (Agostini et al., 2017; Akgun, Keskin \& Bryne, 2007) is showing the work. According to the research study of Hsu and Fang (2009), the interrelation in IC, OLC, and the performance of the development in the new product was analyzed. The findings revealed that intellectual capital, as well as the human capital, is enhanced in the development of the new product by using the OLC. The study of Akgun, Keskin, and Bryne (2007) examined the OLC as a mediator in the emotional capability and innovation in the product. The results highlighted that the OLC is playing the role of partial mediator in the innovation of product and emotional capability. According to Nattrass \& Altomare (1999), OLC is playing a significant role in enhancing the Sustainability of business. The ecofriendly intellectual capital will be influencing the Sustainability of business in a better way when the mediating role of organizational learning and capability will plays a crucial role. So the hypothesis is drawn from the literature is that:

$\mathrm{H}_{4}$ : Organization Learning Capability mediates the relationship between GIC and BS.

\section{Methodology}

The hypotheses proposed model will be evaluated using a quantitative method. The current research uses the survey research approach to address research issues during the discussion of research design. The time horizon for this analysis is cross-sectional since the data are collected once in a while. This principle of research was better considered because the mindset of the respondent does not change during the response. The simple random sampling technique used for data collection. The target respondents received a total of 550 questionnaires. There are two data collection phases in this study. The first stage of data collection was carried out by a self - administered questionnaire between January and March 2020. 154 SMEs manufacturing sector from Lahore, Pakistan, has been selected. The questionnaires were distributed among employees of SMEs accompanied by a cover letter. In two weeks, they were asked to reply and complete the questionnaire. The second data collection phase was distributed within a period of two months (April 2020 to May 2020) by an additional 320 questionnaires. The mailed and online techniques were used. The answer to the questionnaire was provided to the respondents for two weeks. The total number of respondents is 341 , who returned the questionnaire. However, 40 of the questionnaires were incomplete and deleted. For the final analysis, a total of 301 questionnaires have been included, with a $62 \%$ response rate. 


\section{Measurements}

For the sake of data collection, the instrument was adopted containing firstly 18 items adopted from Huang and Kung (2011), to measure the all three dimensions "Green Human Capital, Green Structural Capital, and Green Relational Capital” of green intellectual capital. This instrument was also being adopted in recent studies to measure dimensions of green intellectual capital in various cultures (Firmansyah, 2017; Omar et al., 2017). Chow and Chen (2012) have introduced a scale of business Sustainability. The respondents were asked to evaluate the outputs of the company, which have a total number of items of 22, concerning three key aspects-economic, social and environmental. Organization learning capability has 15 items which are adopted by Chiva et al., (2007) and champs et al., (2011). The items were being measured through 5-point likert scaling from Strongly Agree to Strongly Disagree.

\section{Analysis}

\subsection{Correlation Coefficient}

The correlation coefficient provides a precise analysis of a particular variable. It will have the value from -1.00 to +1.00 . The value of the correlation coefficient of $0.5-1.0$ is considered significant in line with Pallant (2011) and implies the existence of strong relationship between two types of variables independent and dependent. Table 1 below indicates that the targeted variables are having a strong and positive correlation. This analysis thus reveals that green human and structural capital is having positive relation, with a minimal association between 0.061 .

Table No 1: Correlation matrix

\begin{tabular}{|l|l|l|l|l|l|}
\hline & $\mathbf{1}$ & $\mathbf{2}$ & $\mathbf{3}$ & $\mathbf{4}$ & $\mathbf{5}$ \\
\hline Business Sustainability (BS) & 1 & & & & \\
\hline Green Relational Capital (GRC) & 0.074 & 1 & & & \\
\hline Green Structural Capital(GSC) & $0.116^{* *}$ & 0.077 & 1 & & \\
\hline Organization Learning Capability (OLC) & $0.623^{* *}$ & $0.089^{*}$ & 0.074 & 1 & \\
\hline Green Human Capital (GHC) & $0.384^{* *}$ & 0.075 & 0.061 & $0.561^{* *}$ & 1 \\
\hline
\end{tabular}

\subsection{Reliability}

The reliability test alpha value is used for the measurement of internal coherence in each of the variables in each item. Alpha value which is considered acceptable is that value should be above than 0.7. However, the 0.8 or higher than is considered more preferable (Pallant, 2011). Table 2 below shows that the alpha of Cronbach ranges between 0.704 and 0.817 each variable, which indicates a perfect internal consistency.

Table No 2: Reliability analysis

\begin{tabular}{|l|l|l|}
\hline Variable & $\begin{array}{l}\text { No of } \\
\text { items }\end{array}$ & Cronbach alpha \\
\hline Business Sustainability (BS) & 22 & .817 \\
\hline Green Relational Capital (GRC) & 5 & .745 \\
\hline Green Structural Capital(GSC) & 8 & .771 \\
\hline Organization Learning Capability (OLC) & 15 & .775 \\
\hline Green Human Capital (GHC) & 5 & .704 \\
\hline Overall reliability & 55 & .873 \\
\hline
\end{tabular}

\subsection{Multicollinearity}

A multicollinearity measure of the multi - regression variables set is the variance inflation factor (VIF) and tolerance. VIF over 10 and tolerance value under 0.1 indicates that there are high multiple correlations with other variables and suggest multicollinearity possibilities (Pallant, 2011). Table 3 shows that all independent variables are below 10, and the tolerance is above 0.1 , according to the following results from VIF. Diagnostic tests also indicate that the presumption of multicollinearity is not infringed. 
Table 3: Multicollinearity

\begin{tabular}{|l|l|l|}
\hline Variables & \multicolumn{2}{|c|}{ Collinearity statistics } \\
\hline & Tolerance & VIF \\
\hline Green Relational Capital (GRC) & .986 & 1.014 \\
\hline Green Structural Capital(GSC) & .989 & 1.011 \\
\hline Organization Learning Capability (OLC) & .682 & 1.467 \\
\hline Green Human Capital (GHC) & .684 & 1.461 \\
\hline
\end{tabular}

\subsection{Confirmatory Factor Analysis}

The CFA is a particular form of factor analysis, most widely used for social research. Confirmatory Factor Analysis varies from the other "Exploratory Factor Analysis" since the measurements of a building consistent with researchers understanding of the nature of the building (or factor) are used. The goal of CFA is, therefore, to test if the data fit a hypothesized measuring model. CFA is a crucial element in the measuring model in SEM that is used before modeling the structural model to obtain an acceptable model fit. CFA ran in two ways: individual CFA and pooled CFA (Chong et al., 2014). Fitting model measures can be obtained to assess how well the proposed model has captured covariance between all items or measurements in the model. All unnecessary items are either removed or restricted in latent constructions. Loading factor, absolute fitness indexes, incremental, and parsimonious must reach acceptance level. Tables 3 and 4 demonstrate that loading factors for items of variables are far higher than the recommended values of 0.30 . In the present analysis, 10 items of business sustainability have been omitted because of low weights in regression. 6 organization learning capability items were excluded due to low regression weights.

Factor loadings of business sustainability, organizational learning capability, and green structural capital

Table 4: Factor Loadings

\begin{tabular}{|l|l|l|l|l|l|}
\hline \multicolumn{2}{|l|}{ Business sustainability } & \multicolumn{2}{l|}{$\begin{array}{l}\text { Organization learning } \\
\text { capability }\end{array}$} & \multicolumn{2}{l|}{ Green structural capital } \\
\hline Items & Factor loading & Items & $\begin{array}{l}\text { Factor } \\
\text { loadings }\end{array}$ & Items & $\begin{array}{l}\text { Factor } \\
\text { loadings }\end{array}$ \\
\hline BS1 & 0.369 & OLC3 & 0.423 & GSC1 & 0.334 \\
\hline BS2 & 0.558 & OLC7 & 0.524 & GSC2 & 0.451 \\
\hline BS3 & 0.635 & OLC8 & 0.560 & GSC3 & 0.547 \\
\hline BS4 & 0.568 & OLC9 & 0.570 & GSC4 & 0.562 \\
\hline BS5 & 0.489 & OLC10 & 0.392 & GSC5 & 0.507 \\
\hline BS6 & 0.576 & OLC11 & 0.671 & GSC6 & 0.653 \\
\hline BS7 & 0.673 & OLC12 & 0.639 & GSC7 & 0.587 \\
\hline BS8 & 0.488 & OLC13 & 0.461 & GSC8 & 0.644 \\
\hline BS9 & 0.452 & OLC15 & 0.439 & & \\
\hline BS11 & 0.362 & & & & \\
\hline BS13 & 0.305 & & & & \\
\hline BS15 & 0.335 & & & & \\
\hline
\end{tabular}

Factor loadings of green human capital and green relational capital

Table 5: Factor Loadings

\begin{tabular}{|l|l|l|l|}
\hline \multicolumn{2}{|l|}{ Green Human capital } & \multicolumn{2}{l|}{ Green relational capital } \\
\hline Items & Factor loadings & Items & Factor loadings \\
\hline GHC1 & 0.650 & GRC1 & 0.536 \\
\hline GHC2 & 0.782 & GRC2 & 0.439 \\
\hline GHC3 & 0.361 & GRC3 & 0.697 \\
\hline GHC4 & 0.475 & GRC4 & 0.515 \\
\hline GHC5 & 0.384 & GRC5 & 0.620 \\
\hline
\end{tabular}

\subsection{Model Fit Indices}

The fit indices are parsimonious and are tailored to most of the above. We can be modified to equate 
models with different dynamics (equal coefficient numbers). You penalize fewer slothful models, making them superior to simpler models. The more intricate the model, the lower the index fit. Bollen (1989) reported that such a cut is arbitrary, although there are thumb-rules for acceptance of the model fit. Carmines \& McIver, (1981) for instance, discuss that value for CMIN is acceptable in-between 2:1 to 3:1 range. Kline (1998) says that 3 or fewer is acceptable, and others allow values of up to 5 to be considered to fit the model, whereas others emphasize 2 or lower. In the case of RMSEA, if its value is less than or equal to 0.05 , it provides well if it exceeds or equals 0.08 . However, RMSEA $>=0.6$ as the cutoff or suit model suggested by $\mathrm{Hu}$ and Bentler (1999). A 0.85 CFI is more fitting when 0.70 suits the best model of the previous model. The GFI value is appropriate if, as suggested by (Kim, 2007; Yang, 2006), the cost is higher than 0.85. All the benefits that are given in the table below are in an acceptable range.

Table No 6: Confirmatory Factor Analysis (CFA)

\begin{tabular}{|l|l|l|l|l|}
\hline Variables & Chi-square & CFI & GFI & RMSEA \\
\hline Threshold values & $<\mathbf{3}$ & $\mathbf{> 0 . 9 0}$ & $>\mathbf{0 . 8 5 0}$ & $<\mathbf{0 . 0 8}$ \\
\hline Business Sustainability (BS) & 2.601 & .924 & .956 & 0.057 \\
\hline Green Relational Capital (GRC) & 1.583 & .997 & .996 & 0.034 \\
\hline Green Structural Capital(GSC) & 2.323 & .968 & .980 & 0.051 \\
\hline Organization Learning Capability (OLC) & 2.790 & .949 & .970 & 0.060 \\
\hline Green Human Capital (GHC) & 1.155 & .999 & .998 & 0.018 \\
\hline
\end{tabular}

\subsection{Structural Equational Modeling (SEM)}

SEM is a method for predictive testing and assessment of causal relations by integrating mathematical and qualitative variables (Wright, 1921). SEM enables confirmatory and exploratory modeling that is suitable for analytical and theoretical testing. Confirmatory modeling typically begins with a hypothesis expressed in a causal model. To determine the relations among concepts in the model, the concepts employed in the model must then be applied. The model is tested with the measuring data obtained to assess how well the model fits the data.

The causal assumptions in the model are often false and can be checked against the data. With an initial SEM theory, the corresponding model can be specified inductively, and the free parameter values can also be estimated using data. SEM 's strengths include the ability to build latent variables: variables that are not directly measured in the model, but estimated from multiple measured variables, each predicted to "tap" latent variables. The model can thus expressly capture measurement unreliability in the template, which theoretically allows precise estimation of structural relationships between latent variables. Exceptional cases of SEMs are factor analyses, path analyzes, and regression.

Table No 7: Structural equational modeling (SEM)

\begin{tabular}{|l|l|l|l|}
\hline Hypothesis & Estimates & P-value & Result \\
\hline GHC $\longrightarrow$ BS & .144 & $* * *$ & Supported \\
\hline GSC $\longrightarrow$ BS & .141 & .003 & Supported \\
\hline GRC $\longrightarrow$ BS & .071 & .048 & Supported \\
\hline
\end{tabular}

\subsection{Mediation-Analysis}

To confirm the type of mediation, Bootstrap is an essential part of structural equation modeling. It also enables researchers to evaluate the stability of parameter estimates, which can be used in cases where significant and multivariate typical assumptions are not supported. Two models must be built to implement this approach, one with the existence of a mediator and the other with the existence of a mediator. The form of intervention shall be checked according to the recording results explicitly and indirectly. 


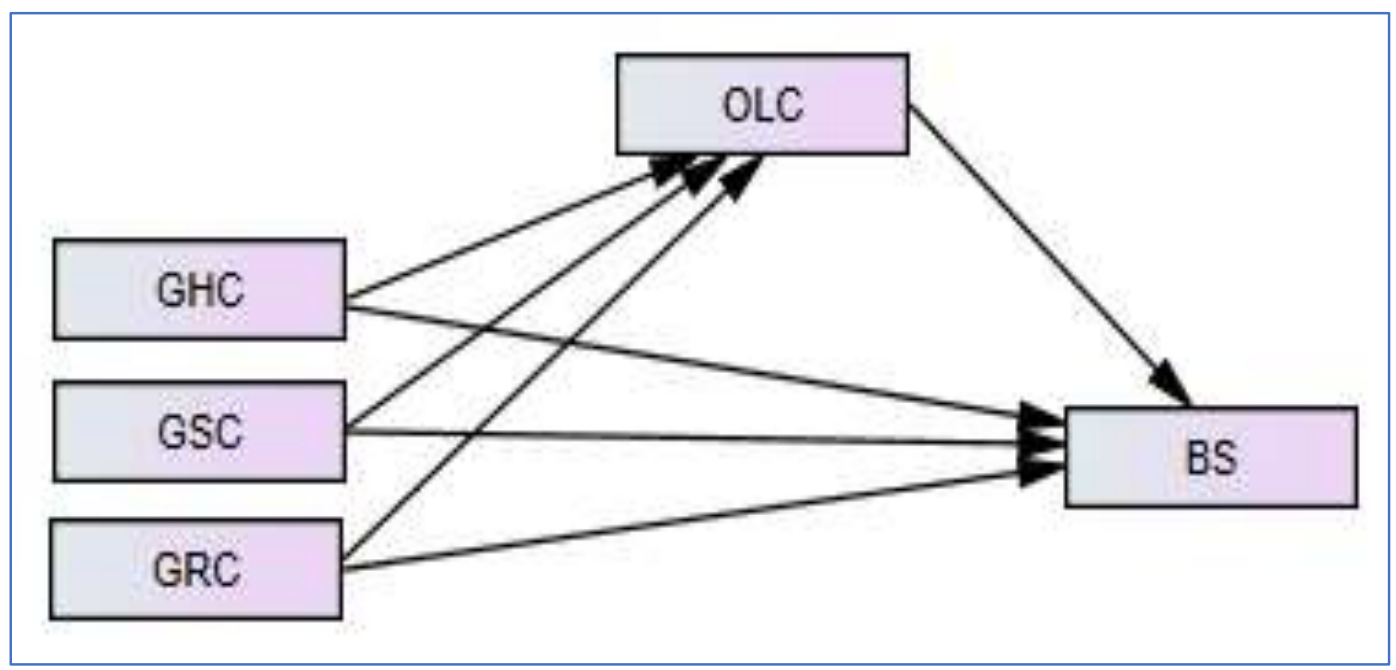

Fig 1: Research model in the context of Pakistan and hypothesis testing Table No 8: Mediation analysis

\begin{tabular}{|l|l|l|l|l|}
\hline \multicolumn{1}{|c|}{ Hypotheses } & $\begin{array}{c}\text { Standardized } \\
\text { Total effect }\end{array}$ & $\begin{array}{c}\text { Standardized } \\
\text { Direct effect }\end{array}$ & $\begin{array}{c}\text { Standardized } \\
\text { Indirect effect }\end{array}$ & \multicolumn{1}{c|}{ Results } \\
\hline GHC-OLC-BS & $.107^{* * *}$ & $.189^{* * *}$ & $.065^{* * *}$ & Partial Mediation \\
\hline GSC-OLC-BS & $.123^{* * *}$ & $.361^{* * *}$ & $.017(\mathrm{NS})$ & No Mediation \\
\hline GRC-OLC-BS & $.132(\mathrm{NS})$ & $.063(\mathrm{NS})$ & $.026(\mathrm{NS})$ & No Mediation \\
\hline
\end{tabular}

\section{Discussion}

To solve the issues prevalent in the environment, the ecofriendly strategies must be adopted quickly. Different researchers have recognized that the GIC will be very much beneficial (Huang and Kung, 2011). Nonetheless, the association in GIC and BS is not studied. So the study will be useful to fill identified literature paucity by examining the impact of "GIC dimensions, on BS". For collecting the data, 154 SMEs in the manufacturing sector, which are operating a business in Lahore is selected. The findings revealed that the connection in the GHC and BS is significant. The result matched with the previous research of Chen and Chang (2013) and (Yong et al. (2019). As the results of these studies showed that the GHC is contributing to increasing the performance of the organization. Another finding revealed that the association of GSC with the BS is positive. The results are consistent with the past research by Chen, (2009), who concluded that the interrelation in competitive advantage and GSC is significant. The early research has also proved that the structural capital is contributing towards a sustainable business (Akhtar et al., 2015). The last results of the study showed that the influence of GRC on the BS is positively significant. The results are aligned with the numerous previous researches (Chen, 2008) that the contribution of GRC is significant towards the performance of the organization. Additionally, the researcher Akhtar et al. (2015) also concluded that there is a correlation in Sustainability and relational capital. The mediating effect of OLC between GHC and BS is thus accepted. $\mathrm{H}_{4 a}$ was, therefore, accepted. Perhaps the plausible reason for manufacturing SMEs to accept the challenges of protecting and retaining good human resources especially for environmental protection. In the relationship between green structural capital (GSC) and BS, OLC has no mediating effect. $\mathrm{H}_{4 \mathrm{~b}}$ has therefore been rejected. Insignificant findings from this study show that accumulated environmental protection knowledge may be smaller as financial and physical constraints are lacking. This study finally found that OLC does not mediate the link between GRC and BS. The good relations between staff and other stakeholders are believed to bring a major change in sharing knowledge with them. The lack of funding may restrict the SMEs to build the relationship between employees and other stakeholders.

\section{Limitations of the Study}

There is some limitation that has been faced by the existing research study. One limitation of the study was that it was conducted in a country that is developing and on SMEs in the manufacturing sector of 
Pakistan. So the generalization of the study is limited in scope. The cross-sectional data was used, which is not providing insight into the changes in the components of GIC over time. The size of the sample of the research was small, which is not providing a conformity of results. Despite the limitations, the study has provided some significant results which have provided insight into the GIC and the Sustainability of business in the SME manufacturing industries of Lahore, Pakistan. It is providing a direction to the future researchers who are planning to examine the significance of GIC on the Sustainability of business.

\section{Suggestions for Future Study}

Notwithstanding a few limits of the study, this can be taken up in different directions. The future researcher can take up other sectors of the industry for examining the association in GIC and the Sustainability of business. The sector of services can be examined too in future research. The study can be undertaken in other emerging countries by taking up similar and different sectors. The study can be conducted using the approach of longitudinal study for investing the change in the variables with a period of time. It will be helpful for the researcher to improve the GIC role on the Sustainability of business. Other variables can also be added for getting the more extensive and wide perspective regarding the factors which is influencing the dependent variable of the study.

\section{Conclusion}

The model which is presented in the study is guiding for the SMEs in the manufacturing sector for determining the influence of different dimensions of GIC on BS. The new strategies of the environment will be used for opening up updated opportunities for the companies to achieve Sustainability. The model can be helpful for the firms to make improvements in their skills with which the cleaner manufacturing can be achieved along with using the different strategies of GIC the business can achieve Sustainability. Additionally, the findings highlighted that the GSC, as well as the GRC, is positively correlated with Sustainability. There the business should focus on these dimensions of GIC.

\section{References}

Aboelmaged, M., \& Hashem, G. (2019). Absorptive capacity and green innovation adoption in SMEs: The mediating effects of sustainable organisational capabilities. Journal of Cleaner Production, 220, 853-863.

Agostini, L., Nosella, A., \& Filippini, R. (2017). Does intellectual capital allow improving innovation performance? A quantitative analysis in the SME context. Journal of Intellectual Capital.

Akgün, A. E., \& Keskin, H. (2014). Organisational resilience capacity and firm product innovativeness and performance. International Journal of Production Research, 52(23), 6918-6937.

Akhtar, C. S., Ismail, K., Hussain, J., \& Umair-ur-Rehman, M. (2015). Investigating the moderating effect of family on the relationship between entrepreneurial orientation and success of enterprise: case of Pakistani manufacturing SMEs. International Journal of Entrepreneurship and Small Business, 26(2), 233-247.

Akhtar, C. S., Ismail, K., Ndaliman, M. A., Hussain, J., \& Haider, M. (2015). Can intellectual capital of SMEs help in their sustainability efforts. Journal of Management Research, 7(2), 82.

Alegre, J., \& Chiva, R. (2008). Assessing the impact of organizational learning capability on product innovation performance: An empirical test. Technovation, 28(6), 315-326.

Ali, U., Noor, M., Khurshid, M. K., \& Mahmood, A. (2015). Impact of firm size on earnings management: A study of textile sector of Pakistan. European Journal of Business and Management, 7(28).

Allameh, S. M. (2018). Antecedents and consequences of intellectual capital. Journal of Intellectual Capital.

Allameh, S. M., \& Abbas, S. K. (2010). The relationship between knowledge management practices and innovation level in organizations: case study of sub-companies of selected corporations in the city of Esfahan. Journal of Business Case Studies (JBCS), 6(1).

Becker, M. C. (2003). The concept of routines twenty years after Nelson and Winter (1982). A review of 
the literature. Industrial and Corporate Change, 643-677.

Bollen, K. A. (1989). A new incremental fit index for general structural equation models. Sociological methods \& research, 17(3), 303-316.

Bontis, N. (1998). Intellectual capital: an exploratory study that develops measures and models. Management decision.

Bontis, N., \& Fitz-enz, J. (2002). Intellectual capital ROI: a causal map of human capital antecedents and consequents. Journal of Intellectual capital.

Bontis, N., Keow, W. C. C., \& Richardson, S. (2000). Intellectual capital and business performance in Malaysian industries. Journal of intellectual capital.

Cai, W., Lai, K. H., Liu, C., Wei, F., Ma, M., Jia, S., ... \& Lv, L. (2019). Promoting sustainability of manufacturing industry through the lean energy-saving and emission-reduction strategy. Science of the Total Environment, 665, 23-32.

Cavicchi, C., \& Vagnoni, E. (2017). Does intellectual capital promote the shift of healthcare organizations towards sustainable development? Evidence from Italy. Journal of Cleaner Production, 153, 275-286.

Chen, B. B., \& Chang, L. (2012). Adaptive insecure attachment and resource control strategies during middle childhood. International Journal of Behavioral Development, 36(5), 389-397.

Chen, C. J., Liu, T. C., Chu, M. A., \& Hsiao, Y. C. (2014). Intellectual capital and new product development. Journal of Engineering and Technology Management, 33, 154-173.

Chen, Y. S., James Lin, M. J., \& Chang, C. H. (2006). The influence of intellectual capital on new product development performance-the manufacturing companies of Taiwan as an example. Total Quality Management and Business Excellence, 17(10), 1323-1339.

Cleff, T., \& Rennings, K. (1999). Determinants of environmental product and process innovation. European environment, 9(5), 191-201.

Cousins, P. D., Handfield, R. B., Lawson, B., \& Petersen, K. J. (2006). Creating supply chain relational capital: The impact of formal and informal socialization processes. Journal of operations management, 24(6), 851-863.

Cui, Z., Zhang, H., Chen, X., Zhang, C., Ma, W., Huang, C., ... \& Gao, Q. (2018). Pursuing sustainable productivity with millions of smallholder farmers. Nature, 555(7696), 363-366.

Davidsson, P., \& Honig, B. (2003). The role of social and human capital among nascent entrepreneurs. Journal of business venturing, 18(3), 301-331.

Del Giudice, M., Maggioni, V., Cruz-González, J., López-Sáez, P., Navas-López, J. E., \& DelgadoVerde, M. (2014). Directions of external knowledge search: investigating their different impact on firm performance in high-technology industries. Journal of Knowledge Management.

Dingemanse, N. J., Dochtermann, N., \& Wright, J. (2010). A method for exploring the structure of behavioural syndromes to allow formal comparison within and between data sets. Animal Behaviour, 79(2), 439-450.

Firmansyah, A. (2018). Pengaruh green intellectual capital dan manajemen lingkungan organisasi terhadap green organizational identity dan dampaknya terhadap green competitive advantage. Substansi: Sumber Artikel Akuntansi Auditing dan Keuangan Vokasi, 1(1), 183-219.

Firmansyah, I., Spiller, M., De Ruijter, F. J., Carsjens, G. J., \& Zeeman, G. (2017). Assessment of nitrogen and phosphorus flows in agricultural and urban systems in a small island under limited data availability. Science of the Total Environment, 574, 1521-1532.

Hart, S. L., \& Dowell, G. (2011). Invited editorial: a natural-resource-based view of the firm: fifteen years after. Journal of management, 37(5), 1464-1479.

Hsu, L. C., \& Wang, C. H. (2012). Clarifying the effect of intellectual capital on performance: the mediating role of dynamic capability. British Journal of Management, 23(2), 179-205.

Hsu, Y. H., \& Fang, W. (2009). Intellectual capital and new product development performance: The mediating role of organizational learning capability. Technological Forecasting and Social Change, 76(5), 664-677.

Hu, L. T., \& Bentler, P. M. (1999). Cutoff criteria for fit indexes in covariance structure analysis: Conventional criteria versus new alternatives. Structural equation modeling: a multidisciplinary 
journal, 6(1), 1-55.

Huang, C. L., \& Kung, F. H. (2011). Environmental consciousness and intellectual capital management. Management decision.

Jabbour, C. J. C., \& de Sousa Jabbour, A. B. L. (2016). Green human resource management and green supply chain management: Linking two emerging agendas. Journal of Cleaner Production, 112, 1824-1833.

Jiang, F., Li, T., Li, Y., Zhang, Y., Gong, A., Dai, J., ... \& Hu, L. (2018). Wood-based nanotechnologies toward sustainability. Advanced Materials, 30(1), 1703453.

Kanwal, A., \& Rajput, A. (2016). A transaction cost framework in supply chain relationships: a social capital perspective. Journal of Relationship Marketing, 15(1-2), 92-107.

Khalique, M., Bontis, N., Shaari, J. A. N. B., Yaacob, M. R., \& Ngah, R. (2018). Intellectual capital and organisational performance in Malaysian knowledge-intensive SMEs. International Journal of Learning and Intellectual Capital, 15(1), 20-36.

Kim, S. K., Davison, M. L., \& Frisby, C. L. (2007). Confirmatory factor analysis and profile analysis via multidimensional scaling. Multivariate Behavioral Research, 42(1), 1-32.

Kor, Y. Y., \& Mahoney, J. T. (2004). Edith Penrose's (1959) contributions to the resource-based view of strategic management. Journal of management studies, 41(1), 183-191.

Lee, S. Y. (2015). The effects of green supply chain management on the supplier's performance through social capital accumulation. Supply Chain Management: An International Journal.

Lin, C. Y., Chen, F., Huang, J. C., Chen, W. C., Liou, Y. A., Chen, W. N., \& Liu, S. C. (2008). Urban heat island effect and its impact on boundary layer development and land-sea circulation over northern Taiwan. Atmospheric Environment, 42(22), 5635-5649.

Liu, C. L. E., Ghauri, P. N., \& Sinkovics, R. R. (2010). Understanding the impact of relational capital and organizational learning on alliance outcomes. Journal of World Business, 45(3), 237-249.

Loh, C. H., Weng, J. H., Liu, Y. C., Lin, P. Y., \& Huang, S. K. (2011). Structural damage diagnosis based on on-line recursive stochastic subspace identification. Smart materials and structures, 20(5), 055004.

Luthans, F., \& Youssef, C. M. (2004). Human, social, and now positive psychological capital management: Investing in people for competitive advantage.

Mårtensson, K., \& Westerberg, K. (2016). Corporate environmental strategies towards sustainable development. Business Strategy and the Environment, 25(1), 1-9.

McIver, J., \& Carmines, E. G. (1981). Unidimensional scaling (No. 24). Sage.

Mehta, K., \& Chugan, P. K. (2015). Green HRM in pursuit of environmentally sustainable business. Pursuit of Environmentally Sustainable Business (June 1, 2015). Universal Journal of Industrial and Business Management, 3(3), 74-81.

Menguc, B., \& Ozanne, L. K. (2005). Challenges of the "green imperative": A natural resource-based approach to the environmental orientation-business performance relationship. Journal of Business Research, 58(4), 430-438.

Morgan, R. M., \& Hunt, S. D. (1994). The commitment-trust theory of relationship marketing. Journal of marketing, 58(3), 20-38.

Omar, M. K., Mohd Yusoff, Y., \& Kamarul Zaman, M. D. (2019). The effect of organizational learning capability as a mediating variable in the relationship between green intellectual capital and business sustainability: evidence from the manufacturing sector. International Journal of Academic Research in Business and Social Sciences, 9, 337-352.

Pallant, J. (2011). SPSS Survival Manual 4th edition: A step by step guide to data analysis using SPSS version 18. Maidenhead, Berkshire: Open University Press. Retrieved on from http://www. allenandunwin. com/spss.

Ray, A. D., \& Grannis, J. (2015). From planning to action: implementation of state climate change adaptation plans. Michigan Journal of Sustainability, 3.

Reed, K. K., Lubatkin, M., \& Srinivasan, N. (2006). Proposing and testing an intellectual capital-based view of the firm. Journal of management studies, 43(4), 867-893.

Sharma, S., \& Aragon-Correa, J. A. (2005). Corporate Environmental Strategy and Competitive 
Advantage-New Perspectives in Research on Corporate Sustainability. New title edition.

Subramaniam, M., \& Youndt, M. A. (2005). The influence of intellectual capital on the types of innovative capabilities. Academy of Management journal, 48(3), 450-463.

Sullivan, K., Thomas, S., \& Rosano, M. (2018). Using industrial ecology and strategic management concepts to pursue the Sustainable Development Goals. Journal of Cleaner Production, 174, 237-246.

Tai-Ning, Y., Hsiao-Chen, C., Shou-Yen, L., \& Chiao-Lun, T. (2011). Knowledge creation and intellectual capital on securities investment services. African Journal of Business Management, 5(3), 924-933.

Widener, S. K. (2006). Associations between strategic resource importance and performance measure use: The impact on firm performance. Management Accounting Research, 17(4), 433-457.

Yong, J. Y., Yusliza, M. Y., Ramayah, T., \& Fawehinmi, O. (2019). Nexus between green intellectual capital and green human resource management. Journal of cleaner production, 215, 364-374.

Yusoff, Y. M., Omar, M. K., \& Zaman, M. D. K. (2019). Practice of green intellectual capital. Evidence from Malaysian manufacturing sector. In IOP Conference Series: Materials Science and Engineering (Vol. 469, No. 1, p. 012008). IOP Publishing.

Yusoff, Y. M., Omar, M. K., Zaman, M. D. K., \& Samad, S. (2019). Do all elements of green intellectual capital contribute toward business sustainability? Evidence from the Malaysian context using the Partial Least Squares method. Journal of Cleaner Production, 234, 626-637.

Zaid, A. A., Jaaron, A. A., \& Bon, A. T. (2018). The impact of green human resource management and green supply chain management practices on sustainable performance: An empirical study. Journal of Cleaner Production, 204, 965-979. 